\title{
Isolation of herpes simplex virus from the cornea in chronic stromal keratitis
}

\author{
C. SHIMELD, A. B. TUllo, D. L. EASTY, AND J. THOMSITT* \\ From the Department of Ophthalmology, University of Bristol, and ${ }^{*}$ West of England Eye Infirmary, \\ Magdalen Street, Exeter
}

SUMMARY Herpes simplex virus was isolated from 2 out of 3 corneal discs of patients with chronic stromal keratitis which were removed during corneal grafting and cultured in vitro.

\begin{abstract}
Although dendritic ulceration of the corneal epithelium due to herpes simplex virus (HSV) frequently resolves with minimal residual damage, ${ }^{1}$ virus may penetrate the corneal stroma and initiate a chronic, recurrent inflammation with an associated fall in visual acuity. The signs of disease in such patients result from the immune response to the presence in the cornea of viral antigen, ${ }^{2}$ which may be expressed by complete or incomplete virus particles, or an antigen on the surface of infected cells and their nuclei. ${ }^{3}$ Despite the demonstration of viral antigen by immunofluorescence, ${ }^{45}$ and of virus particles by electron microscopy, ${ }^{6 \rightarrow}$ it has proved difficult to culture virus in chronic stromal keratitis. We report here the isolation of HSV from 2 such patients, one with chronic ulcerative keratitis and one with recurrent disciform keratitis.
\end{abstract}

\section{Case reports}

\section{PATIENT 1}

A 46-year-old man first attended in February 1975 complaining of a sore right eye present for 4 weeks. $\mathrm{He}$ had been treated with topical steroid and antibiotics. Visual acuity of the left eye was $6 / 6$ and of the right 6/9. Examination revealed a normal left eye and a paracentral dendritic ulcer of the right cornea, which was treated with adenine arabinoside ointment and mydriatics. Despite the resolution of the epithelial lesion a disciform stromal opacity developed, and topical prednisolone was added ( $0.5 \%$ q.d.s.). One month later diffuse stromal and epithelial oedema developed rapidly, associated with uveitis and secondary glaucoma. Gradual resolution occurred over the next 6 months with antiviral, steroid, and antihypertensive drops.

Correspondence to Dr A. B. Tullo, Bristol Eye Hospital, Lower Maudlin Street, Bristol BSi 2LX.
One year after presentation the condition was quiescent, the visual acuity $6 / 18$, and treatment was stopped. An acute flare-up of the keratouveitis required admission to hospital 4 months later. Subsequently the keratitis followed a chronic recurrent course over the following 3 years, so that despite regular attendance corneal anaesthesia, scarring, thinning, and extensive stromal vascularisation developed (Fig. 1), and visual acuity fell to $6 / 60$.

The patient was listed for corneal transplantation, and a penetrating graft using material matched for major histocompatibility antigens was inserted 7 months later (September 1981). At the time of surgery the cornea was relatively quiescent. The patient was using adenine arabinoside ointment and betamethasone drops on alternate days. Postoperative treatment was with systemic steroids $(40 \mathrm{mg}$ prednisolone daily reduced to $2.5 \mathrm{mg}$ daily in 8 weeks)

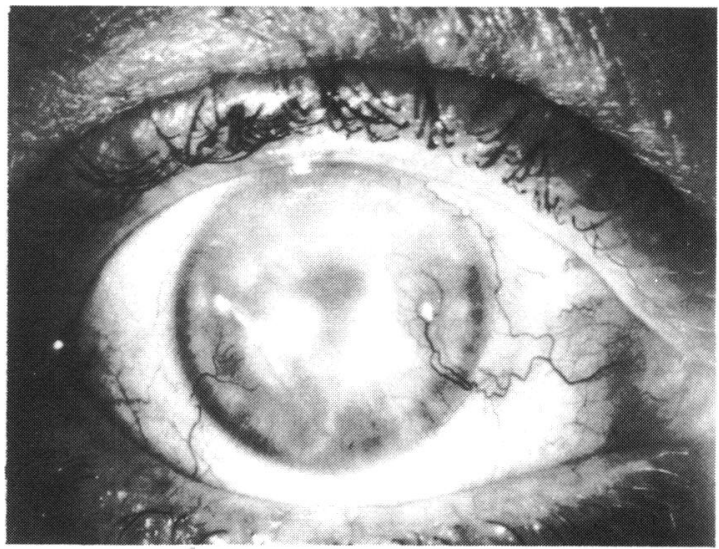

Fig. 1 Right eye of patient 1 one year before surgery, showing corneal opacification and vascularisation. 
and topical trifluorothymidine. The cornea remains clear 8 months after operation and the corrected visual acuity is $6 / 9$.

The patient has a history of herpes labialis but was otherwise healthy. Complement fixing antibodies and evidence of cell mediated immunity to HSV were present before surgery.

\section{PATIENT 2}

A 33-year-old woman first attended in March 1975 with an acute bilateral blepharoconjunctivitis from which HSV was cultured. No vesicles or evidence of keratitis were observed. Within 2 weeks an active disciform keratopathy developed in the left eye, which responded to treatment with topical idoxuridine and prednisolone. The condition flared up 2 months later and responded to the same treatment over 8 weeks, leaving a visual acuity of $6 / 6$. She experienced no further symptoms until November 1977, when she returned with a dense disciform keratitis and visual acuity of hand movements. She responded over 3 months to topical trifluorothymidine and prednisolone, despite a toxic follicular reaction to the antiviral drug. One year later another mild attack occurred, followed by occasional recurrences, all of which responded to a combination of antiviral and steroid therapy. By February 1977 stromal scarring had resulted in a reduction of visual acuity to $6 / 60$. In December 1981 during a course of topical acycloguanosine 5 times a day HSV was again cultured from one conjunctival swab. However, at no time during the history was there evidence of corneal epithelial involvement. After a delay because of pregnancy a penetrating graft was inserted. At surgery the cornea appeared quiescent. The graft remains clear 3 months postoperatively.

\section{PATIENT 3}

A 56-year-old man first attended in 1975 with a dendritic ulcer of the left cornea which progressed to a disciform keratitis, and ultimately to stromal opacification, vascularisation, and lipid keratopathy.

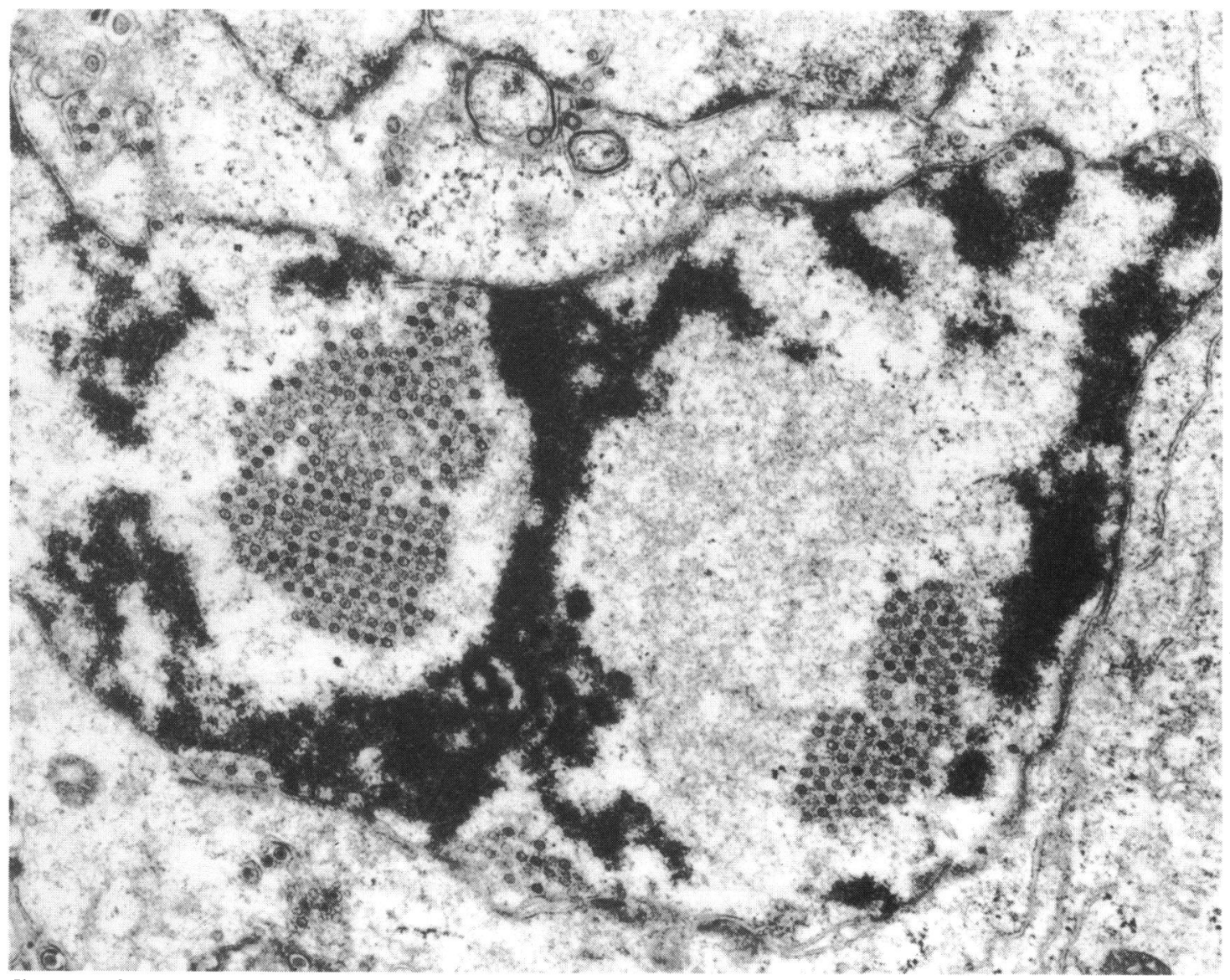

Fig. 2 HSV particles cultured from patient 1 in nucleus and cytoplasm of Vero cell. $(\times 16800)$. (Courtesy of Penny Stirling). 


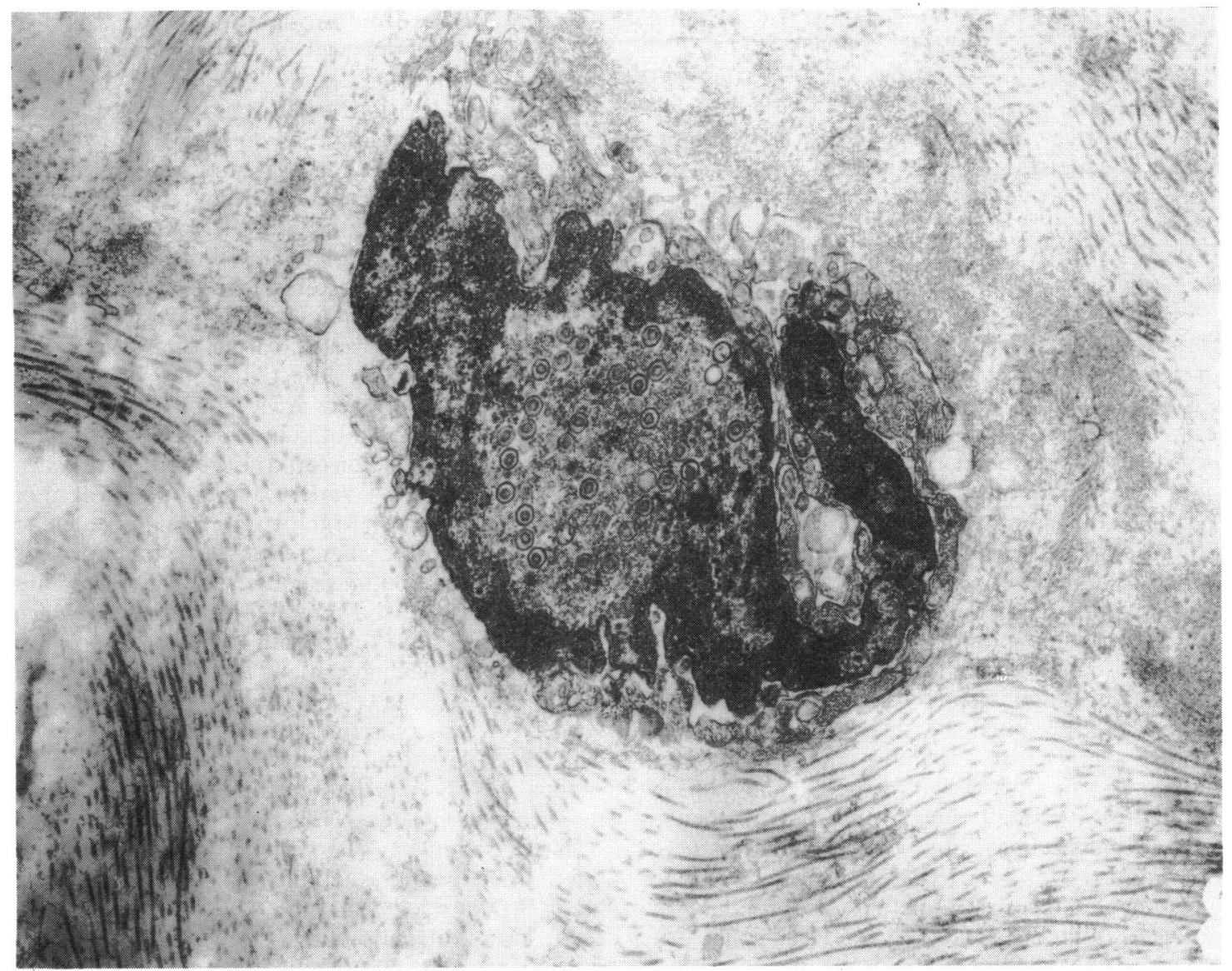

Fig. 3 Active replication of virus in stromal cell of patient 2 showing naked virions and margination of chromatin. (×30900). (Courtesy of Penny Stirling).

He had received combined topical antiviral and steroid therapy. Penetrating keratoplasty was carried out in January 1982. At the time of surgery it was noted that the corneal reflex was absent and that there were no signs of active inflammation. The graft remains clear 4 months postoperatively and the uncorrected visual acuity is $6 / 36$.

The patient has a history of herpes labialis and has complement fixing antibodies to HSV.

ISOLATION OF VIRUS AND ELECTRON MICROSCOPY After removal corneal discs were placed in balanced saline solution (BSS) and kept in a refrigerator at $4^{\circ} \mathrm{C}$ for up to 48 hours, excluding the time taken to reach the laboratory, where they were transferred to $2 \mathrm{ml}$ of growth medium containing $5 \%$ fetal calf serum (FCS) ${ }^{10}$ (patient 1 ) or $20 \%$ FCS (patients 2 and 3). The cornea of the first patient was incubated for 5 days. The cornea of the second patient was incubated for 9 days and supernatant samples were taken on days 4 and 8 . The cornea of the third patient was incubated for 17 days and supernatant samples were taken on days $3,4,6,10,11,12$, and 13 . After removal from growth medium tissue was ground in a glass grinder. Several $50 \mu \mathrm{l}$ samples of the resulting suspension and supernatant samples were placed on Vero cell monolayers in multi dishes. ${ }^{10}$ After incubation in a humidified $\mathrm{CO}_{2}$ incubator at $35^{\circ} \mathrm{C}$ for 48 hours the plates were fixed with alcohol and stain with Giemsa. Cytopathic effect, typical of HSV, was observed due to specimens from the cornea of patient 1 (ground with ease), the corneal supernatant taken on day 8 from patient 2 , and from the specimens from the cornea of patient 2 , which was ground with difficulty. All isolates were identified by neutralisation with antiserum prepared in rabbits. The intranuclear tubules characteristic of HSV type $2^{11}$ were not found in thin sections of infected Vero cells, though virus particles were plentiful (Fig. 2).

In addition the cornea from patient 2 was fixed for 
electron microscopy after being incompletely ground. Most of the scanty cells, which were probably keratocytes, were found to contain many naked virus particles in the nuclei (Fig. 3).

No virus was cultured from the cornea or supernatants of patient 3 , nor were any virus particles seen on electron microscopy of the corneal disc which was fixed on day 17.

\section{Discussion}

It is now well established that HSV may penetrate the corneal stroma, ${ }^{12}$ but difficulty has been encountered in isolating virus from patients with chronic stromal keratitis. Hogan and others ${ }^{13}$ placed portions of corneal discs removed at grafting on to various tissue cultures, rabbit corneas, and the chorioallantois of eggs. Dawson and others ${ }^{6}$ either swabbed the cornea with an applicator which was placed in medium or they minced pieces of excised cornea; the medium or minced tissue was then inoculated into cell cultures. The length of time specimens remained in culture was not stated in either study, but no virus was isolated. Hanna and others ${ }^{14}$ isolated virus from 2 out of 32 patients with stromal keratitis. Specimens were obtained either by scraping the cornea and conjunctiva or by washing the ocular surface repeatedly with sterile culture medium. Specimens were inoculated on to chorioallantoic membrane for 48-72 hours or HeLa cell tissue culture for 14-21 days. It was not stated which method was used in the successful isolation. Moreover the virus could have come from the tear film.

Although HSV was isolated from the corneal discs of 2 patients, we can only speculate on its 3 possible origins. The first patient's initial epithelial lesion preceded the corneal graft by 6 years. Virus penetration of the stroma is thought to be facilitated by topical steroids, ${ }^{15}$ which were used in this case. Thus a chronic low-grade infection of the stroma may have been established. Although disciform keratitis is often preceded by dendritic ulceration this was not the case in the second patient. Nevertheless virus may have penetrated the epithelium in the initial episode, which was most probably a primary infection. In another study the appearance of virus particles on electron microscopy has been interpreted as resulting from an abortive form of replication in degenerating keratocytes, ${ }^{5}$ which may help to explain the difficulties of isolating HSV by the usual culture methods. However, evidence of active replication has also been reported, ${ }^{6}$ and on one occasion it was found to be present in part of the stroma which had appeared normal on slit-lamp examination. ${ }^{16}$ In-vitro systems have been developed in which persistent infection by HSV can be masked by elevated temperature ${ }^{17}$ and by cytosine arabinoside ${ }^{18}$ and in which the presence of virus can be demonstrated only after considerable lag periods by culture methods similar to that described here. Thus in-vitro culture of the cornea may have merely removed the restrictive influences of the immune system or antiviral drugs, which might mask an infection without its eradication.

The isolation method used does not exclude the possibility of latent infection of the cornea. The quiescent nature of the keratocyte is a feature which might favour the incorporation of viral DNA into the cell. HSV has been isolated from clinically normal skin of mice latently infected in the dorsal root ganglion supplying the area. ${ }^{19}$ It has also been isolated from the skin of guinea-pigs in which latent infection of the ganglion could not be demonstrated. ${ }^{20}$ Hoyt and Billson ${ }^{21}$ reported labial herpes after complete transection of the infraorbital nerve due to blow-out fracture, suggesting that virus may be present in human skin without causing disease. Thus the cornea is not the only peripheral site at which chronic or latent infection with HSV may be present. Indeed in the second patient the demonstration of virus in the stromal cells alone strongly suggests that viral DNA was present in these cells at the time of surgery. If latent infection were established in the cornea, it is possible that reactivation was responsible for recurrent episodes of disciform keratitis.

There is ample evidence that after ocular infection latent infection of the nervous system occurs, which is generally considered to be the source of virus causing recurrent epithelial disease..$^{22}$ Such latent infection, particularly of the trigeminal ganglion, would be expected in patients with chronic stromal keratitis. Indeed the intermittent release of virus into the cornea not only provides a third possible source of virus, but might also be responsible for the chronic recurrent nature of the condition. The demonstration by electron microscopy of HSV in failed corneal grafts ${ }^{69}$ indicates that an extracorneal source of virus may be present.

While experimental evidence has indicated that whole virus is not necessary for the induction of stromal disease, ${ }^{5}$ the isolation of infectious virus from these patients, whatever its origin, shows that virus may be present and responsible for causing disease in some patients with stromal keratitis. The comparison of different methods of identifying HSV in the cornea is difficult, because the distribution of virus within the tissue is patchy, ${ }^{6}$ and consequently only one method can properly be applied to each corneal disc. Without access to large numbers of such specimens it is therefore not possible to compare, for example, electron microscopy and organ culture. We therefore felt it worthwhile to report the isolation of HSV, albeit in only 2 cases, by using the method described. 
We are grateful to Drs T. J. Hill and W. A. Blyth for reading the manuscript. The work was supported in part by the Wellcome Trust and South West Regional Health Authority.

\section{References}

1 Norn MS. Dendritic (herpetic) keratitis. Acta Ophthalmol (Kbh) 1970); 48: 91-107.

2 Meyers RL, Chitjiam PA. Immunology of herpes virus infection. Surv Ophthalmol 1976; 21: 194-204.

3 Henson D, Helmsen R, Becker KE, Strano AJ, Sullivan M, Harris D. Ultrastructural localization of herpes simplex virus antigens on rabbit corneal cells using sheep anti-human IgG antihorse ferritin hybrid antibodies. Invest Ophthalmol Visual Sci 1974; 13: 819-27.

4 Pettit TH, Kimura SJ, Peters H. Fluorescent antibody technique in diagnosis of herpes simplex. Arch Ophthalmol 1964; 72: 86-98.

5 Meyers-Elliott RH, Pettit TH, Maxwell WA. Viral antigens in the immune ring of herpes simplex stromal keratitis. Arch Ophthalmol 1980; 98: 897-904.

6 Dawson C, Togni B, Moore TE. Structural changes in chronic herpetic keratitis. Arch Ophthalmol 1968; 79: 740-7.

7 Metcalf JF, Kaufman HE. Herpetic stromal keratitis-evidence for cell-mediated immune pathogenesis Am J Ophthalmol 1976; 82: 827-34.

8 Jones BR, Falcon MG, Williams HP, Coster DJ. Objectives in therapy of herpetic eye disease. Trans Ophthalmol Soc UK 1977; 97: 305-13.

9 Collin HB, Abelson MB. Herpes simplex virus in human cornea, retrocorneal fibrous membrane and vitreous Arch Ophthalmol 1976; 94: 1726-9.

10 Hill TJ, Field HJ, Blyth WA. Acute and recurrent infection with herpes simplex virus: model for studying latency and recurrent disease. J Gen Virol 1975; 28: 341-53.

11 Schwartz J. Roizman B. Similarities and differences in the development of laboratory strains and firstly isolated strains of herpes simplex virus is HEp-2 cell: electron microscopy. J Virol 1969; 4: 879-89.

12 Pettit TH, Meyers RL. Stromal herpes simplex keratitis. Trans Pac Coast Otoophthalmol Soc 1976; 57: 253-61.

13 Hogan MJ, Kimura SJ, Thygeson P. Pathology of herpes simplex kerato-iritis. Am J Ophthalmol 1964; 57: 551-64.

14 Hanna L, Jawetz E, Coleman VR. Studies on herpes simplex: VIII. The significance of isolating herpes simplex virus from the eye. Am J Ophthalmol 1957; 43: 126-31.

15 Robbins R. Galin M. A model for steroid effects in herpes keratitis. Arch Ophthalmol 1974; 93: 828-30.

16 Dawson CR, Togni B. Herpes simplex eye infections: clinical manifestations, pathogenesis and management. Surv Ophthalmol 1976; $21: 121-35$.

17 Kelleher JJ, Varani J, Nelson WW. Establishment of a nonproductive herpes simplex infection in rabbit kidney cells. Infect Immun 1975; 12: 128-33.

18 O'Neill, FJ, Goldberg RJ, Rapp F. Herpes simplex virus latency in cultured human cells following treatment with cytosine arabinoside. J Gen Virol 1972; 14: 189-97.

19 Hill TJ, Harbour DA, Blyth WA. Isolation of herpes simplex virus from the skin of clinically normal mice during latent infection. J Gen Virol 1980; 47: 205-7.

20 Scriba M. Persistance of herpes simplex virus (HSV) infection in ganglia and peripheral tissues of the guinea-pig. Med Microbiol Immunol 1981; 169: 91-6.

21 Hoyt CS, Billson FA. Herpes simplex infection after blow-out fractures. Lancet 1976; ii: 1364-5.

22 Nesburn A, Cook M, Stevens JG. Latent herpes simplex infection from trigeminal ganglia of rabbits with recurrent eye infections. Arch Ophthalmol 1972;88: 412-7. 